\title{
Guava Jam packaging determinant attributes in consumer buying decision
}

\author{
Atributos determinantes da embalagem de goiabada na decisão de compra dos consumidores
}

\author{
Maria Inês Souza DANTAS ${ }^{1}$, Vânia NAKAJIMA ${ }^{1}$ Damiana Diniz ROSA ${ }^{1}$, \\ Fábia Oliveira ANDRADE ${ }^{1}$, Camila CANZIAN ${ }^{1}$, Hércia Stampini Duarte MARTINO ${ }^{1 \star}$
}

\begin{abstract}
Using packaging and labels to lure consumers and to communicate product benefits directly on the shelf is a competitive advantage factor in the food industry sector. The label is especially effective since besides supplying basic details, such as weight, ingredients, and instructions in compliance with governmental regulations, it attracts consumers' attention and the desire to buy and which often becomes synonymous to the brand name. The objective of this study was to obtain detailed information on consumers' attitudes, opinions, behavior, and concepts regarding guava jam packaging using the focus group technique. The results showed that label color and design, packaging type and information, and brand name and price are determinant attributes in the consumers' decision to buy guava jam.

Keywords: focus group; guava jam; packaging.
\end{abstract}

\section{Resumo}

A utilização da embalagem e do rótulo para atrair os consumidores e comunicar benefícios do produto são fatores de vantagem competitiva no setor de indústria alimentício. O rótulo é especialmente efetivo, pois além de fornecer detalhes básicos como peso, ingredientes e instruções, conforme leis governamentais, atrai a atenção dos consumidores e induz desejo de compra, frequentemente tornando-se sinônimo da marca. O objetivo deste estudo foi obter informação detalhada sobre atitude, opinião, comportamento e conceito do consumidor a respeito da embalagem de goiabadas, utilizando a técnica de grupo de foco. Os resultados mostraram que a cor e o design do rótulo, tipo de embalagem, informações nesta contidas, marca e preço são atributos determinantes na decisão de compra de goiabada pelos consumidores avaliados.

Palavras-chave: grupo de foco; goiabada; embalagem.

\section{Introduction}

Guava jam is a product that results from the processing of the edible portion of guava fruit added with sugar, water, jellifying agents, $\mathrm{pH}$ adjusters and other additives. After reaching the desired consistency, it is heat-processed and packed for conservation. Its color ranges from yellowish red to brownish red, and it must keep its guava odor and flavor as well as a gelatinous solid aspect to allow for cutting (MORI; YOTSUYANAGI; FERREIRA, 1998).

In the case of industrialized products, packaging and labels are used to attract the consumer attention and to inform about the benefits of the product at the moment of purchase, thus being a factor of competitive advantage. The labels add value, which promotes product differentiation and increased brand name status among the final consumers. This becomes a factor of utmost importance since the great majority of purchases are decided at the supermarket (SILVEIRA NETO, 2001).

When developing new products or improving the existing ones, it matters to understand how consumers perceive innovations, their expectations, which packaging attributes they consider most attractive, and which information affects positively their buying decision (DI MONACO et al., 2007). Immediate product recognition is important since people visualize 20 of them per second, thus making visual appeal fundamental for purchasing to occur (SILVEIRA NETO, 2001).

Qualitative research is a method used to achieve this desired visual appearance through which detailed information on consumer's attitudes, opinions, perceptions, behavior, habit and practices are assessed. The qualitative data are collected via observation and individual or group interviews (STEWART et al., 1994). The focus group technique is one of the most commonly used research methods, and it is carefully planned and conducted by an experienced moderator sufficiently knowledgeable about the product under discussion (GALVEZ; RESURRECCION, 1992; HASMIN; RESURRECCION; MCWATTERS, 1996). The method is based on group dynamic concepts, and the discussion is stimulated by the exchange of personal comments (GALVEZ; RESURRECCION, 1992). The application of this technique allows to collect adequate amount of data within a short period of time although it might not be possible to confirm participants' spontaneous comments. In spite of that, some of the focus group findings are potentially valuable since they could hardly be collected through simple observation of the facts. Focus group techniques can be used in almost any situation where some preliminary insights can be needed

Received $2 / 2 / 2010$

Accepted 5/6/2010 (003901)

${ }^{1}$ Department of Nutrition and Health, Federal University of Viçosa, Av. Peter Henry Rolfs, s/n. CEP 36570000, Viçosa, MG, Brazil, e-mail: hercia@ufv.br

${ }^{*}$ Corresponding author 
(GIOVINAZZO, 2001). It has been applied in several areas such as marketing, nutrition, sensory analysis and education (LEWIS; YETLEY, 1992; NEUMARK-SZTAINER et al., 1999; DIXEY et al., 2001; WAN; LEE; LEE, 2007). Auld, Kendall and Chipman (1994) applied focus groups to obtain preliminary data focusing on elaborating effective messages to consumers on pesticide use in agriculture and food safety. Deliza, Macfie and Hedderley (1999) applied focus groups to identify fruit juice packaging characteristics relevant to consumers. Focus group sessions were conducted by Costa (1999) as an initial step to identify the parameters considered important by consumers in their perception of vegetable oil packaging so that they could be later included in quantitative studies on sunflower oil. Dantas et al. (2003) worked with a focus group to verify the impact of minimally-processed products on consumers' intention of buying and verify whether price, package color, type, and amount of information displayed on the front shelf are aspects that influence choice and how consumers perceive a product. Di Mônaco et al. (2003) studied the influence of color and brand name on consumers' response to tomato purees through the focus group technique. The results obtained showed that color and brand name seem to be more important than the fresh tomato flavor and that such attributes have affected not only hedonic notions but also sensory perception.

The objective of the present study was to obtain detailed information on attitude, opinion, behavior, and opinion of consumers in relation to guava jam packaging using the focus group technique.

\section{Materials and methods}

\subsection{Participants}

Four focus group sessions were conducted with between seven and nine participants each, undergraduate and graduate students, totalizing 31 participants (10 men and 21 women). Purchasing habits were utilized as criteria for the recruitment of participants into the study.

\subsection{Packaging}

Four guava jam packages with different characteristics purchased from local markets were utilized. Diversification in color, information, and design pattern were the criteria used to select the samples in this study. The description of the four types of packaging is presented on Table 1 . The questions asked aimed at creating a discussion about packaging design, presence and type of information, and consumer's expectation regarding the product in the package.

\subsection{Test}

The sessions were conducted in sufficiently large places to comfortably accommodate people. The participants sat around a rectangular table to allow interaction, visual contact, and harmonious discussion. All sessions were conducted by the same moderator with two assistants to write down all the information. The sessions were also recorded for later analysis.

During the introduction, the moderator defined the purpose of the focus group, the moderator's role, and the study's objective. Each participant introduced him/herself to the group in order to create an interacting atmosphere. The participants were assured that there were no right or wrong answers to the questions presented, and they were encouraged to express their opinions, even if not in agreement with the other members of the group.

The discussion began with questions about their shopping behavior and attitudes in relation to food product packaging. The guava jam packaging samples were presented separately,

Table 1. Description of the packaging used in this study.

\begin{tabular}{|c|c|c|c|c|}
\hline Product & Type of packaging & Color of packaging & Images & Information \\
\hline 1 & $\begin{array}{l}\text { Plastic, cylindrical, } \\
9.5 \mathrm{~cm} \text { diameter lid, } \\
7.5 \mathrm{~cm} \text { bottom } \\
\text { and } 8 \mathrm{~cm} \text { height }\end{array}$ & $\begin{array}{l}\text { Transparent, } \\
\text { red lid, and } \\
\text { yellow label }\end{array}$ & $\begin{array}{c}\text { Guava fruit and women } \\
\text { holding a large pan } \\
\text { containing guava jam }\end{array}$ & $\begin{array}{c}\text { Brand name } \\
\text { Product name (creamy "guava jam") } \\
100 \% \text { natural } \\
\text { Nutrition facts table }\end{array}$ \\
\hline 2 & $\begin{array}{l}\text { Metallic, round, } \\
15 \mathrm{~cm} \text { diameter } \\
\text { and } 3 \mathrm{~cm} \text { height }\end{array}$ & Red & $\begin{array}{c}\text { Brightly colored } \\
\text { Guava fruit }\end{array}$ & $\begin{array}{c}\text { Brand name } \\
\text { Product name (guava jam) } \\
\text { Made with love } \\
\text { Does not contain gluten } \\
\text { Nutritional Information linearly displayed }\end{array}$ \\
\hline 3 & $\begin{array}{l}\text { Metallic, round, } \\
15 \mathrm{~cm} \text { diameter } \\
\text { and } 3 \mathrm{~cm} \text { height }\end{array}$ & Blue & $\begin{array}{c}\text { Brightly colored } \\
\text { Guava fruit }\end{array}$ & $\begin{array}{c}\text { Brand name } \\
\text { Product Name (light guava jam) } \\
50 \% \text { less calories } \\
\text { Made with love } \\
\text { Nutritional information on traditional and } \\
\text { light guava jam linearly displayed } \\
\text { Does not contain gluten }\end{array}$ \\
\hline 4 & $\begin{array}{l}\text { Metallic, cylindrical, } \\
10 \mathrm{~cm} \text { diameter } \\
\text { and } 9.5 \mathrm{~cm} \text { height }\end{array}$ & Yellow & $\begin{array}{c}\text { Red and Yellow } \\
\text { Guava fruit }\end{array}$ & $\begin{array}{c}\text { Brand name } \\
\text { Product name (cascão guava jam) } \\
\text { Home made - pure Minas flavor } \\
100 \% \text { Natural } \\
\text { Nutrition facts table }\end{array}$ \\
\hline
\end{tabular}


and each presentation was followed by a previously established questionnaire (Table 2).

\subsection{Data analysis}

The data was qualitatively analyzed through a content analysis according to Stewart and Shamdasani (1990), and the information was processed and organized into common themes. Topics mentioned in at least two groups were considered important and included in the results summary (BRUG et al., 1995). In addition, all words and their meanings were considered in the analysis, as well as the context in which the ideas were presented, internal consistency, frequency and length of the comments, specificity of the answers, and the importance of identifying the major ideas.

\subsection{Ethics committee}

This project was analyzed and approved by the Human Research Ethics Committee - Federal University of Viçosa, process n. 093/2009, obeying, as outlined, the necessary requirements for its publication.

\section{Results and discussion}

Most participants acknowledge the importance of product labels at the time of purchase by paying special attention to packaging design (color, format, presentation), followed by nutritional information, expiration date, price, and brand.

Table 3 shows the summary of the answers obtained in the sessions regarding the types of packaging used in this study.
Overall, packaging color and design attracted the most the attention of the participants. Red was the most appreciated color associated to the contents, while yellow was rejected by almost all participants. Blue was adequate for light guava jam according to most participants. "The blue color differentiates the product", stated one participant. Another participant said that "the blue color gives the feeling of lightness and fewer calories".

Regarding the printed information, the tiny font used was criticized due to the difficulty to read it. This is an important packaging design, characteristic, and it can be observed in the following sentence: “...color and font size are very important, because it attracts your attention and can lure you into buying...”

The packagings displaying a guava fruit image really pleased the participants since this image was associated to product quality: "...every label should have an image referring to the package content so that there is no need to read the label." However, several participants mentioned that the image should be truthful and natural in order to be attractive. Nutritional information was another attribute considered important, with table display favoring visualization while linear display was strongly criticized.

The majority of the participants said that the guava jam packaging format is important to characterize the product since the round and flat can is already well accepted. Since it is more traditional, this shape evokes consumer's nostalgic childhood memories, as mentioned by some participants “...the good old days..." and "...the fact that it brings you back to the past makes the difference..." However, some consumers criticized the can packaging due to its lack of functionality especially problems

Table 2. Script for conducting the focus group sessions.

\begin{tabular}{cl}
\hline Number & \multicolumn{1}{c}{ Question } \\
\hline 1 & Do you pay attention to the label of the products you consume? \\
3 & What else calls your attention? \\
4 & What did you think of these packaging designs? \\
5 & What did you find important in these packagings? \\
6 & What do you think of the information 'homemade product' on a guava jam packaging? \\
7 & What is the decisive factor in purchasing guava jam? \\
8 & If it said "diet guava jam", would you buy it? \\
9 & Would you be willing to pay more for this product? How much more? \\
\hline
\end{tabular}

Table 3. Summary of answers obtained in the focus group sessions.

\begin{tabular}{|c|c|c|c|c|}
\hline & Packaging 1 & Packaging 2 & Packaging 3 & Packaging 4 \\
\hline Packaging color & Not attractive & Very attractive & Attractive & Not attractive \\
\hline Images & $\begin{array}{l}\text { Does not spark interest to } \\
\text { consume the product }\end{array}$ & $\begin{array}{l}\text { Identifies and draws } \\
\text { attention to the product }\end{array}$ & $\begin{array}{l}\text { Identifies the } \\
\text { product }\end{array}$ & $\begin{array}{c}\text { Does not identify the product; } \\
\text { does not seem real }\end{array}$ \\
\hline $\begin{array}{l}\text { Packaging } \\
\text { format }\end{array}$ & $\begin{array}{l}\text { Although practical, it is not } \\
\text { appropriate for the product. } \\
\text { Looks like seasoning }\end{array}$ & $\begin{array}{c}\text { Traditional, } \\
\text { not practical }\end{array}$ & $\begin{array}{l}\text { Traditional, } \\
\text { not practical }\end{array}$ & $\begin{array}{l}\text { Doesn't look like "guava jam." } \\
\text { Can be confused with milk cus- } \\
\text { tard and wax }\end{array}$ \\
\hline Brand & Known & Known & Known & Unknown \\
\hline $\begin{array}{l}\text { Information } \\
\text { format }\end{array}$ & $\begin{array}{c}\text { Lacks information } \\
\text { and the font size is } \\
\text { too small, which makes } \\
\text { it hard to read }\end{array}$ & $\begin{array}{l}\text { Nutritional information } \\
\text { written in painfully } \\
\text { small font. }\end{array}$ & $\begin{array}{l}\text { The word "Light" is } \\
\text { visible and draws attention. } \\
\text { Remaining information } \\
\text { in small font }\end{array}$ & $\begin{array}{c}\text { The expressions "Minas flavor" } \\
\text { and "100\% natural" draw } \\
\text { consumers's attention. Remaining } \\
\text { information in small font" }\end{array}$ \\
\hline
\end{tabular}


with opening the can, even though it is safe. The plastic packaging was associated to spice's packaging, which can be a negative factor at the time of purchase. Therefore, the format and type of packaging can be decisive in selling the product.

Information such as "guava jam", "100 percent natural" and "Minas flavor" attracted the participants' attention indicating that it has a positive effect on consumers' buying intention. Most of the participants answered that the information "homemade" is a positive factor since it is associated with a more carefully made product, which is more natural and contains less preservatives. However, several participants claimed to be less safe in relation to the microbiological aspects of safe hygienic food manufacture and some associated high price to this type of product. The fact of being registered with the Department of Agriculture and the employment of production quality control management were cited by several participants. They stated: "...there is a necessity to check whether it is homemade and registered because if it is not registered, it is not safe; if it is registered, it is safe". Several studies confirmed consumers' concerns about the quality and microbiological, technological, nutritional, and sensory safety of the products (MCEWAN, 1994; FORD; PENNER; GRUNEWALD, 1998; DANTAS et al., 2003; DELIZA; ROSENTHAL; SILVA, 2003).

Brand, packaging image, and price were considered decisive factors when purchasing guava jam.

With regard to the acceptance of diet guava jam, most participants said they would either not buy it, or buy it only in the event of necessity, such as an illness. They also said they would pay more for this product as long as the price difference between the diet and natural product was not very high. Accordingly, it should be taken into account that the participants of this study are undergraduate and graduate students, who are representatives of a younger and healthier population. Hara (2003) noticed that the age range of consumers of light and diet products is between 26 and 50 years of age, most are married and financially stable, and they are more selective and demanding in terms of making choices and are faithful to their concepts and values.

\section{Conclusions}

Knowing consumers and understanding their needs and behavior are key factors to a commercially successful product. This study showed that label color and design, packaging type and format, information, and brand and price are determining attributes guiding the purchase of guava jam.

As part of a comprehensive study, this research aimed to generate information to investigate the effect of guava jam packaging components on consumers' purchasing intention so as to obtain qualitative data relevant for subsequent stages of analysis.

\section{References}

AULD, G. W.; KENDALL, P. A.; CHIPMAN, H. Consumer and producer perceptions and concerns regarding pesticide use. Food Technology, v. 48, n. 3, p. 100-109, 1994.

BRUG, J. et al. Psychosocial determinants of fruit and vegetable consumption among adults: Results of Focus Group interviews. Food Quality and Preference, v. 6, p. 99-107, 1995. http://dx.doi. org/10.1016/0950-3293(95) $98554-\mathrm{V}$
COSTA, M. C. Tecnologias não convencionais e o impacto no comportamento do consumidor. 1999. 119 f. (Mestrado em Ciência e Tecnologia de Alimentos)-Universidade Federal Rural do Rio de Janeiro, Rio de Janeiro, Brazil, 1999.

DANTAS, M. I. S. et al. The effect of packaging on the perception of minimally processed products. Journal of International Food \& Agribusiness Marketing, v. 16, n. 2, 2003.

DELIZA, R.; MACFIE, H. J. H.; HEDDERLEY, D. An investigation on the package features affecting consumer perception of fruit juice using Repertory Grid and Focus Group methods. Brazilian Journal of Food Technology, v. 2, p. 63-71, 1999.

DELIZA, R.; ROSENTHAL, A.; SILVA, A. L. S. Consumer attitude towards information on non conventional technology. Trends in Food Science \& Technology, v. 14, p. 43-49, 2003. PMid:21299575. http://dx.doi.org/10.1016/S0924-2244(02)00240-6

DI MONACO, R. et al. Consumer acceptability of vegetable soups. Journal of Sensory Studies, v. 22, p. 81-98, 2007. http://dx.doi. org/10.1111/j.1745-459X.2007.00097.x

DIXEY, R. et al. Children talking about healthy eating: data from focus groups with 9-11- year-olds. Nutrition Bulletin, v. 26, p. 71-79, 2001. http://dx.doi.org/10.1046/j.1467-3010.2001.00078.x

FORD, L. T.; PENNER, K. P.; GRUNEWALD, O. Consumer perceptions of HACCP and the price of meat. Dairy Food and Environmental Sanitation, v. 18, p. 735-741, 1998.

GALVEZ, F. C.; RESURRECCION, A. V. A. Reliability of the Focus Group Technique in determining the quality characteristics of Mungbean (VIGNA RADIATA (L.) WILCZEC) noodles. Journal of Sensory Studies, v. 7, p. 315-326, 1992. http://dx.doi.org/10.1111/ j.1745-459X.1992.tb00197.x

GIOVINAZZO, R. A. Focus Group em Pesquisa Qualitativa Fundamentos e Reflexões. Administração On Line, v. 2, n. 4, 2001.

HARA, C. M. O perfil do Consumidor de produtos light e diet no mercado de varejo supermercadista de Campinas. Revista Técnica. FIPEP, v. 3, p. 39-48, 2003.

HASMIN, I. B.; RESURRECCION, A. V. A.; MCWATTERS, K. H. Consumer attitudes toward irradiated poultry. Food Technology, v. 50, n. 3, p. 77-80, 1996.

LEWIS, C. J.; YETLEY, E. A. Focus group sessions on formats of nutritious labels. Journal of the American Dietetic Association, v. 92, p. 62-66, 1992.

McEWAN, J. Consumer attitudes and olive oil acceptance: the potential consumer. Grasas y aceites, v. 45, n. 1-2, p. 9-15, 1994. http://dx.doi. org/10.3989/gya.1994.v45.i1-2.963

MORI, E. E. M.; YOTSUYANAGI, K.; FERREIRA, V. L. F. Análise sensorial de goiabadas de marcas comerciais. Ciência e Tecnologia Alimentos, v. 18, n. 1, p. 105-110, 1998. http://dx.doi.org/10.1590/ S0101-20611998000100022

NEUMARK-SZTAINER, D. et al. Factors influencing food choices of adolescents: findings from focus-group discussions with adolescents. Journal of the American Dietetic Association, n. 99, p. 929-937, 1999. http://dx.doi.org/10.1016/S0002-8223(99)00222-9

SILVEIRA NETO, W. D. Avaliação visual de rótulos e embalagens. 2001. 124 f. Mestrado (Mestre em Engenharia de Produção)Universidade Federal de Santa Catarina, Santa Catarina, 2001.

STEWART, B. et al. Converting focus group data on food choices into a quantitative instrument. Journal of Nutrition Education, v. 26, p. 34 - 36, 1994.

STEWART, D. W.; SHAMDASANI, P. N. Focus groups - theory and practice. California: Newbury Park, 1990. (Sage Publication).

WAN, V. C.; LEE, C. M.; LEE, S. Understanding consumer attitudes on edible films and coatings: focus group findings. Journal of Sensory Studies, v. 22, p. 353-366, 2007. http://dx.doi.org/10.1111/j.1745459X.2007.00108.x 